\title{
Grasshoppers as a food source? A review
}

\author{
Aman Paul ${ }^{\left(1,2^{*}\right)}$, Michel Frederich ${ }^{(3)}$, Roel Uyttenbroeck ${ }^{(1,4)}$, Séverin Hatt ${ }^{(1,5)}$, \\ Priyanka Malik ${ }^{(2)}$, Simon Lebecque ${ }^{(1,6,7,8)}$, Malik Hamaidia ${ }^{(1,9)}$, Krystian Miazek ${ }^{(1)}$, \\ Dorothée Goffin ${ }^{(10)}$, Luc Willems ${ }^{(9)}$, Magali Deleu ${ }^{(6)}$, Marie-Laure Fauconnier ${ }^{(7)}$, \\ Aurore Richel ${ }^{(11)}$, Edwin De Pauw ${ }^{(9)}$, Christophe Blecker ${ }^{(2)}$, Arnaud Monty ${ }^{(4)}$, \\ Frédéric Francis ${ }^{(5)}$, Éric Haubruge ${ }^{(5)}$, Sabine Danthine ${ }^{(2)}$ \\ (1) University of Liège - Gembloux Agro-Bio Tech. TERRA. AgricultureIsLife. Passage des Déportés, 2. \\ BE-5030 Gembloux (Belgium).E-mail: paul.aman@ulg.ac.be \\ (2) University of Liège - Gembloux Agro-Bio Tech. Agrobiochem. Food Science and Formulations Unit. \\ Passage des Déportés, 2. BE-5030 Gembloux (Belgium). \\ (3) University of Liège. Center for Interdisciplinary Research on Medicines. Avenue de l'Hôpital, 1. \\ BE-4000 Liège (Belgium). \\ (4) University of Liège - Gembloux Agro-Bio Tech. Biosystems Engineering. Passage des Déportés, 2. \\ BE-5030 Gembloux (Belgium). \\ ${ }^{(5)}$ University of Liège - Gembloux Agro-Bio Tech. Agrobiochem. Functional and Evolutionary Entomology Unit. \\ Passage des Déportés, 2. BE-5030 Gembloux (Belgium). \\ (6) University of Liège - Gembloux Agro-Bio Tech. Agrobiochem. Laboratory of Molecular Biophysics at Interface. \\ Passage des Déportés, 2. BE-5030 Gembloux (Belgium). \\ (7) University of Liège - Gembloux Agro-Bio Tech. Agrobiochem. General and Organic Chemistry Department. \\ Passage des Déportés, 2. BE-5030 Gembloux (Belgium). \\ ${ }^{(8)}$ University of Liège. Department of Chemistry. Laboratory of Mass Spectrometry. GIGA Systems Biology and Chemical \\ Biology. Building B34. Avenue de l'Hôpital, 1. BE-4000 Liège (Belgium). \\ ${ }^{(9)}$ University of Liège - Gembloux Agro-Bio Tech. Agrobiochem. Molecular and Cell Biology Lab. Passage des Déportés, 2. \\ BE-5030 Gembloux (Belgium). \\ ${ }^{(10)}$ University of Liège - Gembloux Agro-Bio Tech. Innovation and Creativity Cell. Passage des Déportés, 2. \\ BE-5030 Gembloux (Belgium). \\ (11) University of Liège - Gembloux Agro-Bio Tech. Agrobiochem. Unit of Biological and Industrial Chemistry. \\ Passage des Déportés, 2. BE-5030 Gembloux (Belgium).
}

Received on April 10, 2015; accepted on January 12, 2016.

Description of the subject. Current trends suggest an increasing future demand for conventional meats, which indicates a strong need to shift this dependency to other alternative protein sources such as insects.

Literature. From a nutritional point of view, of all the insects consumed globally, grasshoppers are particularly important as a human food. Data from the literature regarding the nutrient composition, amino acid profile, fatty acid profile, mineral composition and vitamin content of grasshoppers as reviewed in this paper, suggest that a number of grasshopper species are a good source of nutrients. It also highlights some of the health related aspects that might arise from the consumption of grasshoppers, mostly linked to agricultural practices and the allergic response of sensitive individuals. The paper also summarizes some religious, social and economic factors that are associated with grasshopper consumption.

Conclusions. The success of introducing grasshoppers as a novel food in western countries depends on changes in consumer attitudes. It would be interesting to develop food products derived from grasshoppers in a form acceptable to consumers. Furthermore, it is important to explore the food potential of some grasshopper species native to western countries and to develop their rearing methodologies to enhance availability.

Keywords. Entomophagy, Orthoptera, human nutrition, environment, health, socioeconomic development.

Les criquets : une nouvelle source d'aliments ? (synthèse bibliographique)

Description du sujet. Du fait de l'augmentation actuelle de la demande en aliments carnés, il devient nécessaire de diversifier les sources de protéines en considérant, par exemple, celles provenant des insectes. 
Littérature. Les criquets représentent une part importante des insectes consommés dans le monde. Diverses études s'intéressent à la composition nutritive, minérale et en vitamines, ainsi qu'aux profils en acides aminés et en acides gras de certaines espèces de criquets et suggèrent que ces dernières auraient une bonne qualité nutritionnelle. De plus, dans cette synthèse bibliographique, les intérêts environnementaux et sanitaires liés à la consommation humaine de criquets sont discutés. Enfin, certains facteurs associés à leur consommation, tels des facteurs religieux, sociaux ou économiques, sont résumés du fait qu'ils peuvent influencer l'intérêt porté à ces insectes.

Conclusions. Le succès de l'introduction des criquets comme aliment, dans des régions où ils ne sont généralement pas consommés, dépend de la capacité du consommateur à modifier son comportement alimentaire. C'est pourquoi, pour le moment, il est essentiel de (1) mettre en évidence les qualités nutritionnelles d'espèces natives, (2) mettre au point des protocoles d'élevages et (3) développer des produits dérivés, afin qu'ils soient mieux acceptés par les consommateurs.

Mots-clés. Entomophagie, Orthoptera, nutrition humaine, environnement, santé, développement socioéconomique.

\section{INTRODUCTION}

In the last few years, changes in the direction and magnitude of global food demand have been observed particularly in developing countries due to rapid urbanization and rising economies. By 2030 , per capita meat consumption in high income countries could increase by $9 \%$, while in developing countries, such as China, the increase could be $50 \%$ when compared to per capita consumption in 2000. This predicted increase in meat consumption would proportionately increase the demand for coarse grain as feed for livestock (Msangi et al., 2011). Approximately $7.5 \mathrm{~kg}$ of plant proteins are required to produce the equivalence of $1 \mathrm{~kg}$ of high quality animal protein (Woodham, 2012). In the future, increasing amounts of feed grain will be needed to produce enough meat to feed an increasing world population. Due to this increasing world population the area under agricultural utilization will probably shrink (Hanafi, 2012) and one of the greatest challenges facing humans will be to produce sufficient feed grain to sustain meat production (Fiala, 2008). Today, insects are increasingly being viewed as an alternative protein source. Indeed, in many regions around the globe, edible insects have long played a vital role in satisfying human nutritional requirements (Banjo et al., 2006). Traditionally, more than 2,000 insect species are consumed worldwide in one or other stages of their life cycle. These insects represent an important part of nutritional intake and economic resources for many societies. Around 524 insect species are estimated to be consumed in Africa, 349 in Asia, 679 in the Americas (mainly Central and South America), 152 in Australia and only 41 in Europe (Jongema, 2015). Mexico has the highest number of insect species that are recognized as edible, followed by Thailand, Congo, India, Australia, China and Zambia (Ramos-Elorduy et al., 2012; Jongema, 2015). Europe clearly presents the lowest number of insect species that are recognized as edible; moreover, insect consumption is not a common practice in that region of the world (Belluco et al., 2013; van Huis et al., 2013; Mlcek et al., 2014).
Some insect species have been found to be highly nutritious; providing a good source of proteins, fats, minerals, vitamins and energy (Ramos-Elorduy et al., 1997). Recent studies reported in the literature indicate that the protein and energy content of insects is quite comparable to that of conventional sources of meat (Ramos-Elorduy et al., 2012; Chakravorty et al., 2014).

The most commonly consumed insect species belong to the Coleoptera (beetles) (31\% of all species consumed), followed by the Lepidoptera (caterpillars) (18\%), the Hymenoptera (bees, ants and wasps) (14\%) and the Orthoptera (grasshoppers and crickets) (13\%) order (Jongema, 2015). These data suggest that insects belonging to the Orthoptera order hold one of the top positions in world entomophagy. This paper reviews the eating of insect species from the Orthoptera order and in particular the families Acrididae, Pyrgomorphidae, Tettigoniidae and Romaleidae.

\section{NUTRIENT CONTENT OF DIFFERENT GRASSHOPPER SPECIES}

Even though grasshoppers produce only one generation per year, they constitute such an enormous biomass that people all over the world dry the insects and then sell and consume them. Most of the grasshopper species in the world are edible (Ramos-Elorduy et al., 2012). Being cold blooded, grasshoppers are effortlessly collected during the coldest part of the day, early in the morning (van Huis et al., 2013).

The food habits of grasshoppers influence their chemical composition (Finke et al., 2014). Insects from the Acrididae, Pyrgomorphidae and Romaleidae families are mostly graminivores. On the other hand, insects from the Tettigoniidae family feed on small insects and the sappy part of plants (Chapman et al., 1990; Capinera, 2008). Studies have indicated that other factors such as sex, stage of life and environmental factors (temperature, day length, humidity, light intensity, etc.) can influence the chemical composition of insects (Finke et al., 2014). 
Tables 1 to 4 summarize data from the literature regarding the nutrient content of some grasshopper species belonging to Acrididae, Pyrgomorphidae, Tettigoniidae and Romaleidae families. The tables also provide information regarding whether the insects used for investigation were wild or reared for food. The country from which the data originate is also specified.

\subsection{The Acrididae family}

Table 1 presents the nutrient content of some grasshopper species from the Acrididae family. Most of the research on the nutritional composition of grasshoppers has been conducted on this family, suggesting that they play an important part in the global consumption of grasshoppers. The protein content of insect species in this family is between 57 and $77 \%$. Data from Mexico on the protein content of this family show a broader variation (57 to $77 \%$ ) when compared to data originating from India (63 to 69\%), not only because they are entirely different species but also due to the fact that they live in a different habitat (Anand et al., 2008; Das et al., 2013; Finke et al., 2014). The fat content of this family is between 4 and $22 \%$. As already mentioned, the sex of insects can also influence the chemical composition. For example, females usually contain more fat before oviposition (Finke et al., 2014). Other factors that may explain these differences include the period of sampling. Some grasshopper species accumulate more fat in later stages of adulthood (Beenakkers et al., 1985). In the same way as for proteins, regional trends can be observed for the lipid data originating from India and Mexico. The amount of crude fiber found in this family varies between 7 and 12\%. Fiber identified in insects may represent a large variety of compounds such as chitin (a carbohydrate derivative), sclerotized proteins, etc. (Finke et al., 2014). Data reported on the ash content in

Table 1. Nutrient content of grasshopper species from the Acrididae family (dry basis) - Valeurs nutritionnelles des espèces de criquets appartenant à la famille des Acrididae (base sèche).

\begin{tabular}{|c|c|c|c|c|c|}
\hline Species (reference) & $\begin{array}{l}\text { Protein } \\
(\%)\end{array}$ & $\begin{array}{l}\text { Fats } \\
(\%)\end{array}$ & $\begin{array}{l}\text { Crude } \\
\text { fiber }(\%)\end{array}$ & $\begin{array}{l}\text { Carbohydrates } \\
(\%) *\end{array}$ & $\begin{array}{l}\text { Ash } \\
(\%)\end{array}$ \\
\hline Acrida exaltala, India; wild (Anand et al., 2008) & 64.46 & 7.07 & 7.73 & 3.64 & 4.98 \\
\hline Arphia fallax, Mexico; wild (Ramos-Elorduy et al., 2012) & 71.30 & 6.52 & 11.58 & 8.11 & 2.41 \\
\hline Boopendon af. flaviventris, Mexico; wild (Rumpold et al., 2013) & 75.95 & 8.43 & 10.35 & 2.32 & 2.95 \\
\hline $\begin{array}{l}\text { Boopendon flaviventris, Mexico; wild } \\
\text { (Ramos-Elorduy et al., 2012) }\end{array}$ & 59.30 & 11.00 & 10.10 & 16.59 & 2.98 \\
\hline Chondacris rosea, India; wild (Chakravorty et al., 2014) & 68.88 & 7.88 & 12.38 & 6.69 & 4.16 \\
\hline $\begin{array}{l}\text { Encoptolophus herbaceous, Mexico; wild } \\
\text { (Ramos-Elorduy et al., 2012) }\end{array}$ & 57.60 & 11.80 & 11.02 & 17.22 & 2.87 \\
\hline Hieroglyphus banian, India; wild (Anand et al., 2008) & 63.61 & 7.15 & 7.16 & 4.81 & 4.86 \\
\hline Melanoplus mexicanus, Mexico; wild (Rumpold et al., 2013) & 77.13 & 4.22 & 12.17 & 4.04 & 2.44 \\
\hline $\begin{array}{l}\text { Melanoplus mexicanus, Mexico; wild } \\
\text { (Ramos-Elorduy et al., 2012) }\end{array}$ & 58.90 & 11.00 & 10.01 & 16.50 & 3.94 \\
\hline Melanoplus sp., Mexico; wild (Rumpold et al., 2013) & 62.93 & - & - & - & - \\
\hline $\begin{array}{l}\text { Melanoplus femurrubrum, Mexico; wild } \\
\text { (Ramos-Elorduy et al., 2007) }\end{array}$ & 77.00 & 4.20 & 12.10 & 4.08 & 2.59 \\
\hline Oxya fuscovittata, India; wild (Anand et al., 2008) & 63.96 & 6.49 & 7.51 & 7.51 & 5.01 \\
\hline Schistocerca sp., Mexico; wild (Ramos-Elorduy et al., 1997) & 61.00 & 17.00 & 10.00 & 7.00 & 4.60 \\
\hline Schistocerca sp., Mexico; wild (Rumpold et al., 2013) & 61.10 & 17.00 & 10.00 & 7.00 & 4.60 \\
\hline Spathosternum prasiniferum, India; wild (Anand et al., 2008) & 65.88 & 8.11 & 6.96 & 6.36 & 5.11 \\
\hline $\begin{array}{l}\text { Spathosternum prasiniferum prasiniferum, India; wild } \\
\text { (Das et al., 2013) }\end{array}$ & 65.15 & 7.15 & 6.91 & 6.32 & \\
\hline Trimerotropis pallidipennis, Mexico; wild (Rumpold et al., 2013) & 62.93 & 22.20 & 7.63 & 2.63 & 4.79 \\
\hline Trimerotropis sp., Mexico; wild (Ramos-Elorduy et al., 2012) & 65.10 & 7.02 & 10.20 & 10.20 & 3.78 \\
\hline
\end{tabular}


Table 2. Nutrient content of grasshopper species from the Pyrgomorphidae family (dry basis) - Valeurs nutritionnelles des espèces de criquets appartenant à la famille des Pyrgomorphidae (base sèche).

\begin{tabular}{|c|c|c|c|c|c|}
\hline Species (reference) & $\begin{array}{l}\text { Protein } \\
(\%)\end{array}$ & $\begin{array}{l}\text { Fats } \\
(\%)\end{array}$ & $\begin{array}{l}\text { Crude } \\
\text { fiber }(\%)\end{array}$ & $\begin{array}{l}\text { Carbohydrates } \\
(\%)^{*}\end{array}$ & $\begin{array}{l}\text { Ash } \\
(\%)\end{array}$ \\
\hline $\begin{array}{l}\text { Chrotogonus trachypterus trachypterus, India; wild } \\
\text { (Das et al., 2013) }\end{array}$ & 59.63 & 15.92 & 7.89 & 6.34 & 8.55 \\
\hline Sphenarium borrei, Mexico; wild (Ramos-Elorduy et al., 2012) & 63.70 & 10.40 & 9.81 & 12.40 & 3.96 \\
\hline Sphenarium histrio, Mexico; wild (Ramos-Elorduy et al., 1997) & 77.00 & 4.00 & 12.00 & 4.00 & 2.00 \\
\hline Sphenarium histrio, Mexico; wild (Rumpold et al., 2013) & 74.78 & 8.63 & 10.53 & 2.59 & 3.47 \\
\hline $\begin{array}{l}\text { Sphenarium histrio (nymphs, adults), Mexico; wild } \\
\text { (Ramos-Elorduy et al., 2007) }\end{array}$ & 71.15 & 6.72 & 11.79 & 8.01 & 2.30 \\
\hline $\begin{array}{l}\text { Sphenarium mexicanum, Mexico; wild } \\
\text { (Ramos-Elorduy et al., 2012) }\end{array}$ & 62.10 & 10.80 & 4.06 & 22.64 & 0.34 \\
\hline Sphenarium purpuracens, Mexico; wild (Melo et al., 2011) & 71.50 & 5.75 & 3.89 & 16.36 & 2.50 \\
\hline $\begin{array}{l}\text { Sphenarium purpuracens, Mexico; wild } \\
\text { (Ramos-Elorduy et al., 1997) }\end{array}$ & 56.00 & 11.00 & 9.00 & 21.00 & 3.00 \\
\hline Sphenarium purpuracens, Mexico; wild (Rumpold et al., 2013) & 52.60 & 19.56 & 11.04 & 14.49 & 2.31 \\
\hline $\begin{array}{l}\text { Sphenarium purpuracens, Mexico; wild } \\
\text { (Ramos-Elorduy et al., 2012) }\end{array}$ & 65.20 & 10.80 & 9.41 & 11.63 & 2.95 \\
\hline Sphenarium sp., Mexico; wild (Rumpold et al., 2013) & 67.02 & 7.91 & 10.67 & 8.12 & 6.28 \\
\hline Zonocerus variegatus, Nigeria; wild (Ademolu et al., 2010) & 62.73 & 2.49 & 3.61 & 29.40 & 4.11 \\
\hline
\end{tabular}

*: \% carbohydrates: see table 1 - voir tableau 1.

Table 3. Nutrient content of grasshopper species from the Tettigoniidae family (dry basis) - Valeurs nutritionnelles des espèces de criquets appartenant à la famille des Tettigoniidae (base sèche).

\begin{tabular}{|c|c|c|c|c|c|}
\hline Species (reference) & $\begin{array}{l}\text { Protein } \\
(\%)\end{array}$ & $\begin{array}{l}\text { Fats } \\
(\%)\end{array}$ & $\begin{array}{l}\text { Crude } \\
\text { fiber }(\%)\end{array}$ & $\begin{array}{l}\text { Carbohydrates } \\
(\%)^{*}\end{array}$ & $\begin{array}{l}\text { Ash } \\
(\%)\end{array}$ \\
\hline Conocephalus triops, Mexico; wild (Ramos-Elorduy et al., 2012) & 71.00 & - & - & - & - \\
\hline $\begin{array}{l}\text { Idiarthron subquadratum, Mexico; wild (Ramos-Elorduy et al., } \\
\text { 2012) }\end{array}$ & 65.20 & 8.17 & 11.10 & 4.42 & 3.79 \\
\hline Ruspolia differens (brown), Kenya; wild (Kinyuru et al., 2011) & 44.30 & 46.20 & 4.90 & 2.00 & 2.60 \\
\hline Ruspolia differens (green), Kenya; wild (Kinyuru et al., 2011) & 43.10 & 48.20 & 3.90 & 2.00 & 2.80 \\
\hline
\end{tabular}

-: data not available - données non disponibles; *: \% carbohydrates: see table 1 - voir tableau 1.

Table 4. Nutrient content of grasshopper species from the Romaleidae family (dry basis) - Valeurs nutritionnelles des espèces de criquets appartenant à la famille des Romaleidae (base sèche).

\begin{tabular}{llcccc}
\hline Species (reference) & $\begin{array}{l}\text { Protein } \\
(\%)\end{array}$ & $\begin{array}{l}\text { Fats } \\
(\%)\end{array}$ & $\begin{array}{l}\text { Crude } \\
\text { fiber }(\%)\end{array}$ & \multicolumn{1}{l}{$\begin{array}{l}\text { Carbohydrates } \\
(\%)\end{array}$} & $\begin{array}{l}\text { Ash } \\
(\%)\end{array}$ \\
\hline Romalea sp., Mexico; wild (Ramos-Elorduy et al., 2012) & 75.30 & 12.30 & 9.73 & 0.13 & 4.25 \\
Romalea colorata, Mexico; wild (Ramos Elorduy et al., 2001a) & 71.98 & 16.25 & 6.30 & 0.09 & 4.59 \\
$\begin{array}{l}\text { Taeniopoda auricornis, Mexico; wild (Ramos-Elorduy et al., } \\
\text { 2012) }\end{array}$ & & 10.20 & 8.34 & 14.52 & 3.97 \\
Taeniopoda sp., Mexico; wild (Ramos-Elorduy et al., 2012) & 71.00 & 5.85 & 10.56 & 9.59 & 2.95 \\
\hline
\end{tabular}

*: \% carbohydrates: see table 1 - voir tableau 1. 
the insects of the Acrididae family can be seen to vary from 2 to $11 \%$. Oonincx et al. (2011) suggested that the level of ash content in some grasshoppers varies depending upon the stage of maturity. A considerable decrease in the ash contents of some species was observed during the maturation from penultimate instar into the adult (Oonincx et al., 2011). Very few reports have quantified the carbohydrate content of grasshoppers. When not available in literature, an approximation of carbohydrate content was made by deducing the sum of all the other components (protein, fat, ash, fiber and moisture) present in the body from 100 (Rumpold et al., 2013). The level of carbohydrate content reported in the data analyzed has thus been identified as lying between 2 and $17 \%$.

\subsection{The Pyrgomorphidae family}

Table 2 presents the nutrient composition of some of the grasshopper species from the Pyrgomorphidae family. The insects of this family are usually found in tropical and sub-tropical areas (Chapman et al., 1990; Ramos-Elorduy et al., 2012; Das et al., 2013). Grasshoppers of the Pyrgomorphidae family are commonly consumed in Mexico and in many African countries (Ramos-Elorduy et al., 1997; Ademolu et al., 2010). The protein and lipid content of insects from this family are between 52 and $77 \%$ and between 2 and $20 \%$, respectively. This family exhibits polyphagous feeding behavior (Chapman et al., 1990; Capinera, 2008). Hence, the availability of a protein rich diet may result in higher protein content in the insects. However carbohydrate rich diets (where carbohydrates are metabolized into fat) may change the chemical composition of the insect's body (Finke et al., 2014). Crude fiber, ash and carbohydrate content for this family are in the range of 3 to $12 \%, 0$ to $9 \%$ and 2 to $30 \%$, respectively (Table 2). In some insects exceptionally high levels of carbohydrates ranging between 20 and $30 \%$ have been observed (Ramos-Elorduy et al., 1997; Ademolu et al., 2010; Ramos-Elorduy et al., 2012). With the emergence of adulthood the amount of chitin in the body of some insects from the Pyrgomorphidae family has been found to increase (Ademolu et al., 2010), and this could be one of the reasons to explain this high carbohydrate content. Food remaining in the gastro-intestinal tract of insects may also influence the analyzed carbohydrate content (Finke et al., 2014).

\subsection{The Tettigoniidae family}

The nutrient composition of some of the grasshopper species from the Tettigoniidae family is shown in table 3. Very few efforts have been made to explore the food potential of insect species from this family. The literature shows a large variation in protein (43 to
$71 \%$ ) and lipid content (8 to $48 \%$ ) (Table 3). However it would be interesting to compare data originating from different geographical locations. The data show that the protein content of insects from Mexico was found to lie between 65 and $71 \%$, while the levels for those from Kenya were found to be between 43 and $44 \%$. One of the main reasons to explain this difference in the levels of protein content could be the carbohydrate rich diets of Ruspolia differens Serville (Kenya). These insects mainly feed on carbohydrate rich grains such as rice, millet, sorghum and maize (van Huis et al., 2013). Further this dietary carbohydrate is metabolized into fat (Finke et al., 2014), this also accounts for changes in the value of other components (crude fiber, ash and carbohydrates). Because of its exceptionally high fat content, grasshopper species $R$. differens has played an important role in the nutrition of many African communities. Fat improves the palatability of food and is essential to the maintenance of proper body functioning. However it is important to remove the fat from these insects prior to storage in order to avoid undesirable changes occurring due to lipid oxidation (Kinyuru et al., 2011). In view of their high fat content, these insects could also be used as a commercial source of lipids.

\subsection{The Romaleidae family}

Table 4 presents the nutrient composition of some of the grasshopper species from the Romaleidae family. Insects from this family are found only in the Neotropical region. They are large and robust, and have a colorful appearance. These insects exhibit a polyphagous feeding behavior (Chapman et al., 1990; Ramos Elorduy et al., 2001a; Capinera, 2008). The data show that the protein, lipid, crude fiber, ash and carbohydrate contents in this family have been found to vary from 63 to $75 \%, 6$ to $16 \%, 6$ to $11 \%, 3$ to $5 \%$ and 0 to $15 \%$ respectively. Romalea colorata $\mathrm{S}$. has been shown to contain a considerably low level of carbohydrates. However, investigations regarding other edible insects have revealed carbohydrate levels as low as $0.06 \%$ (Rumpold et al., 2013).

In summary, the data presented here show that the average levels of protein content found in the Acrididae, Pyrgomorphidae, Tettigoniidae and Romaleidae families were $65.68 \%, 65.24 \%, 55.90 \%$ and $70.32 \%$ respectively (all of these measurements were made on a dry basis). Comparing these levels to the protein contents of soy beans $(39.9 \%)$, meat from animals such as beef and chicken $(40.5 \%$ and $54.7 \%)$ on a dry basis (Chakravorty et al., 2014), grasshoppers potentially represent an alternative source of protein, especially in regions with limited availability/affordability of meat.

The quality of protein consumed is also of great importance. Indeed, a food with a high protein content 
could present a low protein digestibility (Melo et al., 2011). In this context, during a laboratory feeding experiment, rats who were fed a diet based on Zonocerus variegatus $\mathrm{L}$. showed a food efficiency ratio (gain in body weight/food intake) of 0.44 and a proteins efficiency ratio (gain in body weight/protein intake) of 1.90. In comparison, rats fed with a soybean based diet showed a food efficiency ratio of 0.27 and a proteins efficiency ratio of 1.12. The proteins from $Z$. variegatus present a better digestibility when compared to soy proteins (Solomon et al., 2008). Due to its high levels of proteins and excellent protein digestibility, this species could be used for the preparation of various high protein foods (Ademolu et al., 2010; Solomon et al., 2008).

The amino acid content of some edible grasshopper species is shown in table 5. Phenylalanine, valine, threonine, tryptophan, methionine, leucine, isoleucine, lysine and histidine cannot be synthesized by the human body. These are qualified as essential amino acids because they can be supplied to the body only by food (WHO, 2007; Finke et al., 2014). Data reviewed in this paper show that most of the grasshopper species investigated meet the amino acids requirements proposed by the World Health Organization (WHO, 2007). Moreover, grasshoppers can be viewed as a very good source of phenylalanine (22 to $117 \mathrm{mg} \cdot \mathrm{g}^{-1}$ protein). This amino acid plays a vital role in several biochemical processes including the synthesis of neurotransmitters, thyroxine and melanin (Stargrove et al., 2008). No specific trends can be observed in the amino acid data even amongst insects that belong to the same family.

Studies containing extensive protein analysis of grasshoppers can be found in the literature. However, to date, few studies have been devoted to the fat composition of grasshoppers. The fatty acid composition of some edible grasshopper species, as published in the literature, is reported in table $\mathbf{6}$. The table shows the reported levels of saturated fatty acids, monounsaturated fatty acids and polyunsaturated fatty acids (PUFA) for grasshopper species to be as follows: $27.91 \pm 16.05 \%, 26.38 \pm 5.18 \%$ and $44.90 \pm$ $12.34 \%$ respectively. In most cases linoleic acid and $\alpha$-linolenic acid are shown to be among the essential fatty acids present in the highest proportions in the grasshoppers (Kinyuru et al., 2011). The fatty acid composition of insects varies with individual species, their developmental phase, diet and environmental factors (Finke et al., 2014).

Using data derived from the literature, table 7 presents the mineral compositions of some edible grasshopper species, together with the recommended daily intake of various minerals for adults (mg.100 g based on dry matter). Again a large variation can be observed among the reported values. Of 19 grasshopper species analyzed for magnesium content, 13 meet the recommended daily requirements (WHO, 2004). Dietary magnesium is very important for calcium metabolism; it also participates in various important chemical reactions in our body (Challem, 2003). The data reveal that grasshoppers represent a poor source of calcium. This is due to the fact that these insects do not have a mineralized skeleton (Finke et al., 2014). On the other hand, all grasshopper species investigated contain sufficient zinc to meet the recommended daily requirements. Zinc in the body forms an integral part of many enzymes and is important for the body's immunity (Challem, 2003).

In addition to minerals, grasshoppers contain several vitamins. Table 8 presents data derived from the literature regarding the vitamin content of some grasshopper species, together with the recommended daily intakes of these vitamins. Zonocerus variegatus (adult) fulfills the daily requirement for vitamin A (retinol) in the human body (Ademolu et al., 2010) (Table 8). On the other hand R.differens (brown and green) fulfills the daily requirement for vitamin B2 (riboflavin) and vitamin B9 (folic acid) (Kinyuru et al., 2011). The presence of all these vitamins, which play an important role in proper body functioning (Challem, 2003) also makes grasshoppers an interesting source of food.

\section{ENVIRONMENTAL ASPECTS}

Consuming grasshoppers as food can also prove beneficial from an environmental point of view, both in terms of breeding and of harvesting from nature.

Greenhouse gas emissions from livestock production play a significant part in the total human induced gas emissions (Steinfeld et al., 2006). In the USA, methane emissions associated with enteric fermentation and manure management constitute $31 \%$ of total methane emissions, which is the largest contributor of these emissions, ranking even above the petroleum industry (U.S. Environmental Protection Agency, 2015). Studies indicate that the highest levels of carbon dioxide equivalents are being released from beef production, followed by pork and chicken (Fiala, 2008). Two-thirds of the ammonia generated from agricultural activities originate from livestock production. Ammonia is further responsible for the eutrophication of surface water and soil acidification (Steinfeld et al., 2006). Another study revealed that one of the commercially bred grasshopper species Locusta migratoria $\mathrm{L}$. produces no methane, $2.37 \mathrm{~g}$ of carbon dioxide equivalents, and $5.4 \mathrm{mg}$ of ammonia per kg body mass every day. These levels are very low in comparison with beef which produces up to $0.28 \mathrm{~g}$ of methane, $7.08 \mathrm{~g}$ of carbon dioxide equivalents, 
Table 5. Amino acid profile of some edible grasshopper species $\left(\mathrm{mg} \cdot \mathrm{g}^{-1}\right.$ protein $)$ - Profil en acides aminés de quelques espèces comestibles de criquets ( $m g \cdot g^{-1}$ de protéine).

\begin{tabular}{|c|c|c|c|c|c|c|c|c|c|c|}
\hline Species (reference) & $\mathbf{H}$ & $\mathbf{I}$ & $\mathbf{L}$ & $\mathbf{K}$ & M & $\mathbf{C}$ & $\mathrm{M}+\mathrm{C}$ & $\mathbf{F}$ & $\mathbf{Y}$ & $\mathbf{F}+\mathbf{Y}$ \\
\hline $\begin{array}{l}\text { Boopendon flaviventris (Guevara et al., } \\
\text { 1995) }\end{array}$ & 24.0 & 47.0 & 88.0 & 55.0 & 18.0 & - & - & 41.0 & 74.0 & 115.0 \\
\hline $\begin{array}{l}\text { Boopendon flc } \\
\text { (Ramos-Elord }\end{array}$ & 24.0 & 47.0 & 0 & .0 & 18.0 & 20.0 & 38.0 & 41.0 & 74.0 & 115.0 \\
\hline Chondacris rosea (Chakravorty et al., 2014) & 28.3 & 50.8 & 84.7 & 53.4 & 5.1 & - & - & 38.3 & 61.1 & 99.4 \\
\hline Chrotogonus trachypte & 46.9 & 12.6 & 50.7 & 30.4 & 12.4 & 4.3 & 16.7 & 49.6 & 115.2 & 164.8 \\
\hline $\begin{array}{l}\text { Melanoplus femurrubrum } \\
\text { (Ramos-Elorduy et al., 2012) }\end{array}$ & 23.1 & 26.4 & 58.2 & 61.7 & 29.8 & 11.6 & 41.4 & 22.5 & 56.4 & 78.9 \\
\hline Patanga succinate ( $\mathrm{Yh}$ & 13.5 & 32.7 & 59.5 & 35.7 & - & - & 20.9 & - & - & 60.0 \\
\hline $\begin{array}{l}\text { Spathosternum prasini } \\
\text { (Das et al., 2013) }\end{array}$ & 53.9 & 12.4 & 51.3 & 59.5 & 17.8 & 6.9 & 24.7 & 41.6 & 96.5 & 138.1 \\
\hline al., 2012) & .0 & 53.0 & 0 & .0 & 20.0 & 13.0 & 33.0 & 17.0 & 73.0 & 190.0 \\
\hline $\begin{array}{l}\text { rascens } \\
\text { t al., 2012) }\end{array}$ & 220 & 42.0 & 89.0 & 57.0 & 25.0 & 18.0 & 43.0 & 103.0 & 63.0 & 166.0 \\
\hline Sphen & - & 42.0 & 85.0 & 57.0 & 42.0 & - & - & 77.0 & - & - \\
\hline $\begin{array}{l}\text { rnis } \\
\text { t al., 2012) }\end{array}$ & 14.8 & 41.2 & 42.5 & 41.5 & 18.9 & 10.7 & 29.6 & 51.2 & 76.4 & 127.6 \\
\hline $\begin{array}{l}\text { Amino acid requirements in hu } \\
\text { 2007) }\end{array}$ & 15.0 & 30.0 & 59.0 & 45.0 & 16.0 & 6.0 & 22.0 & - & - & 30.0 \\
\hline Species (reference) & & $\mathbf{T}$ & $\mathbf{W}$ & $\mathbf{V}$ & $\mathbf{R}$ & $\mathbf{S}$ & $\mathbf{P}$ & $\mathbf{A}$ & $\mathbf{G}$ & $\mathbf{E}$ \\
\hline Boopendon flaviventris (C & & 44.0 & 6.0 & 57.0 & - & - & - & - & - & - \\
\hline $\begin{array}{l}\text { Boopendon flaviventris (Ramos-Elorduy et al., } \\
\text { 2012) }\end{array}$ & & 44.0 & 6.0 & 57.0 & 43.0 & 43.0 & 68.0 & 59.0 & 75.0 & 154.0 \\
\hline Chondacris rosea (Chakravorty et al., 2014) & & 44.1 & - & 68.3 & 66.6 & 47.0 & 69.0 & 118.4 & 71.6 & 114.6 \\
\hline Chrotogonus trachypterus (Das et al., 2013) & & 155.0 & 24.2 & 61.4 & 83.0 & 50.4 & 169.6 & 28.5 & 79.4 & 30.6 \\
\hline $\begin{array}{l}\text { Melanoplus femurrubrum (Ramos-Elorduy et a } \\
\text { 2012) }\end{array}$ & & 37.0 & 6.4 & 40.9 & 32.1 & 29.4 & 26.6 & - & - & 62.6 \\
\hline Patanga succinate (Yhoung-aree, 2008) & & 22.3 & 17.3 & 35.6 & 36.0 & 23.9 & 48.7 & 92.7 & 48.8 & 76.4 \\
\hline Spathosternum prasiniferum (Das et al., 2013) & & 177.7 & 23.3 & 60.5 & 72.5 & 45.5 & 159.3 & 31.5 & 84.0 & 37.5 \\
\hline Sphenarium histrio (Ramos-Elorduy et al., 201 & & 40.0 & 6.0 & 51.0 & 66.0 & 51.0 & 72.0 & 76.0 & 53.0 & 53.0 \\
\hline $\begin{array}{l}\text { Sphenarium purpurascens (Ramos-Elorduy et } \\
\text { 2012) }\end{array}$ & al., & 31.0 & 7.0 & 57.0 & 60.0 & 48.0 & 62.0 & 64.0 & 68.0 & 107.0 \\
\hline Sphenarium purpurascens (Melo et al., 2011) & & 39.0 & 6.0 & 56.0 & - & - & - & - & - & - \\
\hline Taeniopoda auricornis (Ramos-Elorduy et al., & , 2012) & 20.6 & 5.8 & 49.0 & 35.9 & 32.9 & - & 59.5 & 30.6 & 68.3 \\
\hline Amino acid requirements in humans (WHO, 20 & 2007) & 23.0 & 6.0 & 39.0 & - & - & - & - & - & - \\
\hline
\end{tabular}

$\mathrm{H}$ : histidine - histidine; I: isoleucine - isoleucine; L: leucine - leucine; K: lysine - lysine; M: methionine - méthionine; C:

cysteine - cystéine; F: phenylalanine - phénylalanine; Y: tyrosine - tyrosine; T: threonine - thréonine; W: tryptophan -

tryptophane; V: valine - valine; R: arginine - arginine; S: serine - sérine; P: proline - proline; A: alanine - alanine; G: glycine glycine; E: glutamic acid - acide glutamique; -: data not available - données non disponibles. 
and $170.00 \mathrm{mg}$ of ammonia (Oonincx et al., 2010). This shows that commercial breeding of this particular grasshopper species might be favorable in terms of greenhouse gas emissions. However, more studies related to greenhouse gas emissions from other grasshopper species still need to be conducted. Studies on the life cycle assessment of the environmental impact linked to mealworm (Tenebrio molitor L.) rearing have suggested that the production of this insect could be more sustainable in terms of greenhouse gas production and land use when compared to conventional meat sources (Oonincx et al., 2012). It would be interesting to perform similar life cycle assessment studies linked to the production of some of the edible grasshopper species.

Approximately 22000 to 430001 of water are required to produce $1 \mathrm{~kg}$ of beef (van Huis, 2013). Some scientists believe that unlike cattle, most insects meet their water requirement from food. As a result, they require much less water to grow (van Huis, 2013; Shockley et al., 2014). Some grasshopper species feed only on grass (Chapman et al., 1990) and quite a large amount of water are required for grass cultivation (Hartin et al., 2001). However, locust species such as Schistocerca gregaria Forskal exhibit polyphagous feeding behavior. Instead of feeding only on grass they eat a large variety of plants from different taxonomic groups based on availability. Because of this behavior (Chapman et al., 1990), this species can even survive in areas with very little rainfall (Food and Agriculture Organization, 2001). Furthermore, it would be interesting to study the commercial breeding of this locust species and to gain estimations of water requirements.

Some grasshopper and locust species including S.gregaria, Melanoplus foedus Scudder and Taeniopoda eques Burmeister are known to be involved in carnivory/ necrophagy. This behavior ensures the disposal of dead organic matter such as their own dead hatchings, other insects, and a large variety of organic matter (Seino et al., 2013). Feasibility studies on rearing orthopterans such as crickets (Acheta domesticus L.) on organic side streams have been successfully conducted (Lundy et al., 2015). Similar feasibility studies on the mass rearing of edible grasshopper species on bio waste streams still need to be performed.

On the other hand, harvesting grasshoppers from their natural habitat or from crops can also result in environmental advantages such as natural habitat protection and reduced pesticide 


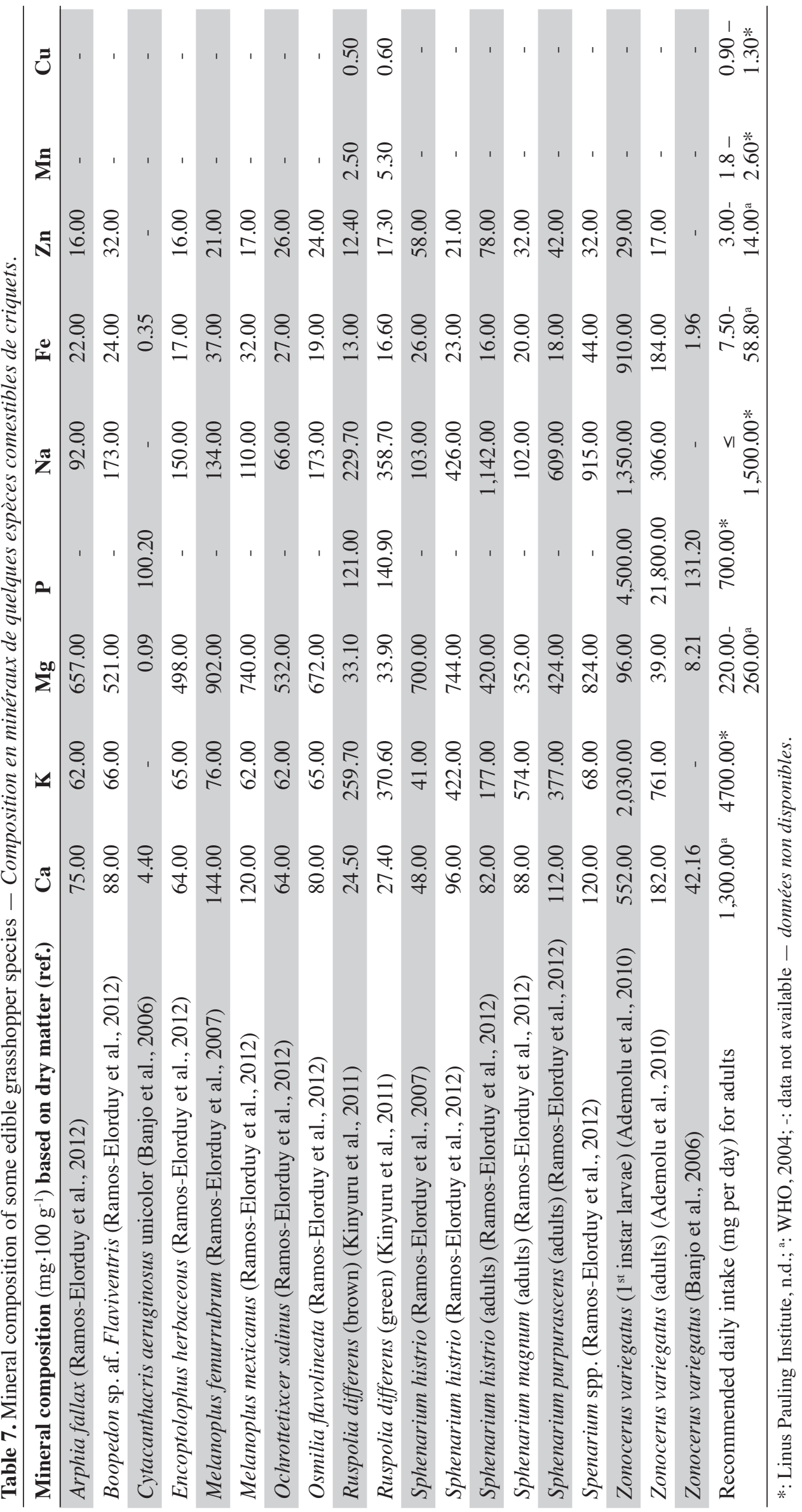


use. Using wild insects as food may sound contradictory to the need for their conservation. However, using insects as food can result in the enhancement of biodiversity conservation in several ways (DeFoliart, 1997; Yen, 2009). First of all, it is possible to develop sustainable harvesting protocols in order to protect the edible species (Yen, 2009). Moreover, the need for local populations to protect edible insects for their own food security can result in the protection of the habitats of these insects, e.g. caterpillars in Zambia forests (DeFoliart, 1997). Protection of the habitats concerned can also be enhanced by using the edible insects as flagship species for their habitat (Yen, 2009). Furthermore, the use of insects as an alternative food source can reduce the environmental pressure caused by the normal food source. One example is the reduction of poaching witnessed in wild game reserves when local people are allowed to sustainably harvest the insect populations (DeFoliart, 1997). Another important factor in the use of insects as food source is the reduction of livestock grazing which is responsible for environmental destruction (Yen, 2009).

When populations of these insects build up, certain species exhibit gregarious and migratory behavior, leading to the formation of spectacular swarms. From their mention in the Bible to current media reports, these locust plagues attract public attention in a way that no other insects do; the image of a flying swarm of locusts from the desert descending onto crops never fails to stir the human conscience (van Huis et al., 2013). Predominant crops (corn, bean and alfalfa) in the Puebla-Tlaxcala Valley (Mexico) are routinely attacked by the grasshopper Sphenarium purpurascens Charpentier (Cerritos et al., 2008; Torres et al., 2011). The traditional method for managing this pest in Mexico has been the application of organophosphorus insecticides such as malathion. Inhabitants from Central Mexico also capture the grasshoppers for sale as food (Cerritos et al., 2008). Some authors have reported that the manual harvesting of insects that can be utilized for food is a practical method of pest control and that this could be extensively applied in other crop systems around the world (Cerritos et al., 2008; Yen, 2009). Despite being a very attractive prospect, this method cannot, however always be applied and/ or be sufficient to reduce the pest population. In past years, Thai people have witnessed fierce attacks by the Patanga succincta L. grasshopper species on maize crops. A wide range of insect control methods including the aerial spraying of insecticides has been unsuccessful in controlling the insect. Subsequently, a systematic campaign to eradicate the devastating effects of grasshoppers prompted their use as an alternative food source in Thailand (Roffey, 1979). As a result, grasshoppers have become an important part of Thai cuisine as a delicacy. Harvesting pest insects 
can thus reduce pesticide use while at the same time creating a food source (DeFoliart, 1997).

\section{HEALTH ASPECTS}

Grasshopper consumption by humans is sometimes associated with positive health effects. Large scale livestock production activities have been associated with the risk of livestock diseases, which may result in the emergence of new and sometimes antibiotic resistant pathogenic strains (King et al., 2006). By contrast, some scientists suggest that insects are taxonomically more distant than livestock from humans, and that they therefore exhibit a lesser chance of posing such health risks (van Huis, 2013).

Some traditional remedies involving the use of grasshoppers have been reported in Mexican culture. The crushed hind legs of grasshoppers from Sphenarium spp., Taenipoda sp. and Melanoplus sp. are diluted and drunk as a diuretic. These insects are also used to treat some intestinal disorders. In addition, pulverized insects of Schistocerca spp. are consumed as a dietary supplement with the objective of curing nutritional deficiencies (Ramos-Elorduy de Conconi et al., 1988). However, most of these claims are based on traditional knowledge and to date no clinical data or chemical investigations have been reported in support. Research is required to confirm scientifically these uses of grasshoppers in traditional remedies, and to identify the compounds responsible for their action in the human body. If clinical trials are favorable, extracts from grasshoppers or the whole edible insect could be promoted as functional foods.

Besides the reported health benefits, some health risks that may arise from the consumption of grasshoppers have also been recorded in the literature. Belluco et al. (2013) reported elevated levels of lead in dried grasshoppers from Mexico, which was shown to increase blood lead levels in California children and pregnant women who consumed those grasshoppers. Elevated levels of heavy metals in food are probably due to environmental contamination or food preparation methods.

Pesticide application is traditionally the control strategy that is most widely used against grasshoppers (Cerritos et al., 2008). These chemicals induce toxic residues in host grasshoppers. This may also pose a health risk to the individuals that consume these contaminated insects (Yen, 2009). However, one solution to this problem could be the production of these grasshoppers in controlled conditions (farm rearing) where feed could be monitored in order to ensure food safety.

Some grasshoppers have large spines on the shinbone; if these are not removed before consumption they can cause intestinal damages. Such cases often require surgery to remove the spines (van Huis et al., 2013). Some species of grasshoppers are also known to release chemical secretions as part of their defense mechanism (Hill et al., 2012). The chemical composition of these secretions varies quite considerably depending upon the species. Compounds found in secretions and reported in the literature include phenols, plant toxins and proteinase inhibitors. Secretions are produced in the metathoracic tracheal glands and the composition depends on the diet of the insects concerned (Chapman et al., 1990). Predators usually avoid these species. Those who ignore the warning signs and consume them often become listless or timid; they vomit and acquire a strong food aversion condition against future consumption of these species. In some cases, grasshopper consumption (particularly of the Pyrgomorphidae family) has been associated with the death of guinea fowl. There is also one reported case of the death of a human child after consumption of the insects from this family (Hill et al., 2012). This makes proper identification of the grasshopper species necessary before consumption in order to ensure the avoidance of insects that generate these secretions.

Moreover, many individuals exhibit allergies towards specific food or environmental conditions. Three kinds of allergy have been reported in association with grasshoppers. The first kind is the occupational allergy observed in individuals involved in the rearing of grasshoppers, where patients have reported problems of rhinitis, asthma and dermatitis. The second kind is the allergy resulting from being exposed to large numbers of grasshoppers aggregating in the field; in this case patients have reported asthma and even a few cases of death have been observed. The third category is the allergy resulting from grasshopper consumption, where anaphylaxis has been observed (Yen, 2009; Mlcek et al., 2014; Pener, 2014). These allergic reactions may be due to the hypersensitive response of the immune system to a particular stimulus (Pener, 2014). More research is required to study the mechanism of the physiological reaction of such sensitive individuals towards the chemical components that grasshoppers either produce or contain (proteins, etc.).

Some species of grasshopper serve as intermediate hosts to several avian parasites and horsehair worms, including several species that have been reported as accidentally infesting humans (Fink et al., 2004). The spiruid nematode, Tetrameres americana Cram, is a common parasite of free range chickens. The North American grasshopper species Melanoplus femurrubrum De Geer, Melanoplus differentialis Thomas, and the Caribbean \& South American species Rhammatocercus cyanipes $\mathrm{F}$. are known to serve as vectors of T. americana. Grasshoppers ingest the feces 
of avian hosts which carry the eggs of T. americana. The larvae become infective after 42 days of entering the grasshoppers and are found in all parts of the insect's body. Poultry birds eat these grasshoppers and become the final hosts. Heavy infection may cause anemia and weight loss in birds. Grasshoppers are also known to be vectors of some tapeworm species. Horsehair worms develop as parasites in some grasshoppers. When mature, these worms leave the host body to lay eggs in water. There are some incidences where humans have accidently consumed the worms. In most cases the worms were vomited out shortly after being ingested, although in a few cases, they apparently survived in the intestines for several months before being expelled (Hill et al., 2012).

\section{OTHER ASPECTS}

The influence of religion, food preparation and preservation techniques, socio-economic factors and future needs are also important aspects affecting grasshopper consumption. Religions and traditions have historically influenced regional food practices. Eating insects has been mentioned in various places in the religious literature of Christianity and Islam. The Bible quotes the consumption of grasshoppers in the book of Leviticus (XI: 21-22), while the religious literature of Islam grants permission to eat grasshoppers at Sahih Muslim, 21.4801, Sunaan ibn Majah, 4.3222 and Sunaan ibn Majah, 4.3219-3220 (El-Mallakh et al., 1994; Meyer-Rochow, 2009). These religious citations have served to promote the consumption of grasshoppers as food in many parts of the world. However it is important to note that these citations have not been able to successfully incite entomophagy in western countries.

Most of the grasshopper species, irrespective of their maturity stage are consumed when and wherever they are harvested. People prefer to consume female grasshoppers as after the rainy season, they contain more fat and carry eggs. In some areas of the world the sale of grasshoppers brings in more money than base crops (van Huis, 2013). For this reason, farmers avoid using pesticides during production. The legs and wings of the grasshopper are usually removed before consumption. Grasshoppers are sometimes fried or roasted before consumption, they are often sun dried, powdered and consumed with porridge (van Huis et al., 2013). Grasshoppers from the species Chondracris roseapbrunner Uvarov are commonly available for sale in Thai markets during the period from May to October and they fetch a price of around 8 USD per $\mathrm{kg}$. People eat these grasshoppers after steaming, frying or roasting them (Siriamornpun et al., 2008). Cooking of insects not only renders them palatable but also improves their nutritional properties. It was found that boiling of some edible insects significantly improves the biological value of proteins (proportion of proteins from the food which is absorbed in body) (Ekpo, 2011). A report indicated the presence of some plant based toxic compounds (such as oxalates and phytates) in edible insects. The authors also suggested that cooking of these insects could reduce the level of such toxins (Alamu et al., 2013).

Literature suggests that cooking of insects can also alter some of their functional properties. It was found that generally cooking could improve the protein solubility. Water absorption capacity of some insect larvae significantly decreased after roasting and grilling (Womeni et al., 2012). These properties could be interesting for companies which are trying to develop value added products either by incorporating grasshoppers as an ingredient or else completely using grasshoppers, in order to encourage their consumption as a food in areas where they are not currently consumed.

Collecting and selling insects harvested from the wild has offered new opportunities for people in developing countries. Financially underprivileged people such as women and landless individuals can readily participate in the collection, processing and sale of insect products (Yen, 2009). In some African communities, harvesting edible insects provides cash to cover basic expenses such as daily food, buying agricultural inputs and even paying for educational fees (Kelemu et al., 2015). Most of the grasshoppers that are consumed in Thailand are imported from Cambodia. This trade has generated income for many unemployed Cambodian people who are involved in the harvesting and marketing chain of grasshoppers (Hanboonsong et al., 2013). In this way entomophagy has improved the economic condition of many people at both community and country levels. Many people in rural areas of Africa, Latin America and Asia suffer from under nutrition particularly in the form of protein-energy malnutrition. Because of economic limitations, many people in developing countries are not able to afford meat (Siriamornpun et al., 2008). In this situation harvested insects offer an economical substitute, as insects and meat provide similar nutrition to human body (Banjo et al., 2006). A wide variety of edible insects are readily available and they serve as an important protein source to people living in these conditions (Siriamornpun et al., 2008). As already reviewed in this paper, grasshoppers contain high levels of good quality proteins. Consumption of these insects has long helped low-income countries to shield themselves against protein-energy malnutrition. In this way, the consumption of grasshoppers as a food source has already improved the life of people in developing countries both economically and nutritionally. 
Eating insects is prominent in most of the tropical areas of the world owing to the fact that (a) insects tend to be larger in size there, which facilitates their harvesting; (b) insects often congregate in large numbers so large quantities can be collected in a single harvest; and (c) a variety of insects are available all year round (van Huis et al., 2013). A study originating from Thailand, reported that a large variety of insects are available for human consumption in the country throughout the year depending upon the season (Siriamornpun et al., 2008). Seasonal availability of insects has also been mentioned in reports from India and Nigeria (Banjo et al., 2006; Chakravorty et al., 2014). Tropical regions exhibit warm to hot conditions throughout the year. However, in temperate regions the weather is hot in summers and cold in winters (Lye, 1997). Being cold blooded, insects find it easy to grow in tropical areas where the weather is favorable throughout the year (Chapman et al., 1990; Capinera, 2008). This explains the limited availability of insects in temperate regions during the cooler months. So, in order to encourage the consumption of grasshoppers as a human food in temperate areas, especially the western world, these insects need to be farmed. This could lead to a substantial amount of biomass being available for human consumption throughout the year (Haldar et al., 1999; van Huis, 2013). Another point that has already been mentioned in $\S 2.2$. is that farming grasshoppers could be one of the ways to ensure food safety.

DeFoliart (1999) explained the importance of local insect species in nutrition and society. Some scientists are of the view, that importing edible insect species in Europe would mean catching the insects from places where there is a greater need for them and transferring them in a lesser ecological way (Mlcek et al., 2014). Instead of importing insects, some countries, such as The Netherlands, have already started small scale farming of species such as L. migratoria for human consumption (van Huis et al., 2013). However, very few efforts have been made to explore the nutritional potential of some native grasshopper species from these countries. It is possible that local individuals may find it easier to accept these native species as food because they have already been around them. The commercial rearing of these insects would require minimum capital to maintain environmental conditions as they are already adapted to local conditions and rearing of these insects for food can also open new employment opportunities for locals.

Efforts have already been made to breed insects from the Acrididae family in the laboratory. One particular laboratory based study on the farming of the grasshopper Oxya fuscovittata Marschall resulted in the production of $1 \mathrm{~kg}$ of biomass in 29-35 days by 84 females (Haldar et al., 1999). More studies are needed to develop the commercial breeding of grasshoppers in order to enhance the biomass quantity and yearlong availability. Furthermore specialized diets can be used to feed grasshoppers to improve their biomass quality and strengthen their role in human nutrition. A study where L. migratoria was fed on different diets suggested that altering the diet could significantly change the chemical composition of these insects. Higher amounts of lipids were observed in the body when the insects were fed on a grass + wheat bran and a grass + wheat bran + carrot diet in comparison with a grass only diet. Furthermore, the carrot based diet increased the $\beta$-carotene concentration in the body of the insects (Oonincx et al., 2011).

Despite the fact that grasshoppers exhibit a large number of qualities that make them a possible important future food, consumer attitudes represent the most important factor influencing westerners in their choice over whether to initiate the practice of entomophagy. Consuming insects as food induces a feeling of fear, anxiety and aversion in some people (Caparros Megido et al., 2014). However, due to the efforts of public and private institutions, the consumption of insects is gaining acceptance in the western countries (DeFoliart, 1999). To facilitate the consumption of insects as food, attention could be focused on the sensory factors related to acceptance and on increasing awareness amongst consumers in order to eliminate neophobia. Preparing insect with a pleasant flavor (e.g. with a chocolate taste), a crispy texture (crispier than a pastry) and the use of small insects or even invisible ones (e.g. introduced in the form of flour) are more likely to be appreciated. People are usually neophobic towards insects due to a fear of the unknown, so informing consumers would increase the acceptance of insects as a food source. Finally, increasing consumer exposure to edible insects, for example, organizing experimental tasting sessions would diminish neophobia (Caparros Megido et al., 2014). Studies have shown that it is easier for the younger generation to adopt insects as a novel food source (Verbeke, 2015). However, the inability of a product to meet the expectations of individuals consuming insects for the first time could risk developing its perceived unacceptability (Tan et al., 2015).

\section{CONCLUSIONS}

Grasshoppers hold an important position in global entomophagy; apart from the nutritional interest in these insects, some researchers have also reported that their consumption could be beneficial for environmental reasons. Some social views and the citings of religious texts have also supported the consumption of grasshoppers. Traditionally, these 
insects have been used to cure a broad spectrum of health disorders. However, the health risks arising due to agricultural practices such as residual pesticides and heavy metals, parasitic association and the allergic response of sensitive individuals cannot be ignored. It has been observed that westerners particularly Europeans, do not consume insects as food, and that they did not do so even in ancient times. One of the reasons behind this could be the poorer availability of insects in these countries, associated with their environmental conditions. In order to encourage the consumption of grasshoppers in the western world commercial rearing needs to be developed to enhance the year-long availability of a safe and quality biomass. Furthermore, it would be interesting to explore the nutritional potential of some native grasshopper species in Europe and to develop their commercial rearing; this could be an ecological alternative to the importing of exotic species and would probably have a greater chance of acceptance from local populations. As entomophagy often induces a feeling of fear and aversion in people, systematic campaigns such as organizing tasting and information sessions aiming to change consumer attitudes would need to be planned, especially in the western world. Furthermore, a great deal of research is still required regarding the development value-added products from grasshoppers. These new products would present the insects in a more acceptable form to consumers in western countries, enabling to be successfully promoted and established as a future food source.

\section{Acknowledgements}

This research was made possible from the financial support of the CARE AgricultureIsLife, University of Liège Gembloux Agro-Bio Tech, Belgium.

\section{Bibliography}

Ademolu K.O., Idowu A.B. \& Olatunde G.O., 2010. Nutritional value assessment of variegated grasshopper, Zonocerus variegatus (L.) (Acridoidea: Pygomorphidae), during post-embryonic development. Afr. Entomol., 18(2), 360-364.

Alamu O.T. et al., 2013. Diversity and nutritional status of edible insects in Nigeria: a review. Int. J. Biodivers. Conserv., 5(4), 215-222.

Anand H., Ganguly A. \& Haldar P., 2008. Potential value of acridids as high protein supplement for poultry feed. Int . J. Poult. Sci., 7(7), 722-725.

Banjo A.D., Lawal O.A. \& Songonuga E.A., 2006. The nutritional value of fourteen species of edible insects in southwestern Nigeria. Afr. J. Biotechnol., 5(3), 298301.
Beenakkers A.M., Van der Horst D.J. \& Van Marrewijk W.J., 1985. Insect lipids and lipoproteins, and their role in physiological processes. Prog. Lipid Res., 24(1), 19-67.

Belluco S. et al., 2013. Edible insects in a food safety and nutritional perspective. Compr. Rev. Food Sci. Food Saf., 12(3), 296-313.

Caparros Megido R. et al., 2014. Edible insects acceptance by Belgian consumers. J. Sens. Stud., 29(1), 14-20.

Capinera J.L., 2008. Encyclopedia of entomology. $2^{\text {nd }} \mathrm{ed}$. Springer Science \& Business Media.

Cerritos R. \& Cano-Santana Z., 2008. Harvesting grasshoppers Sphenarium purpurascens in Mexico for human consumption: a comparison with insecticidal control for managing pest outbreaks. Crop Prot., 27(35), 473-480.

Chakravorty J., Ghosh S., Jung C. \& Meyer-Rochow V.B., 2014. Nutritional composition of Chondacris rosea and Brachytrupes orientalis. J. Asia-Pac. Entomol., 17(3), 407-415.

Challem J., ed., 2003. User's guide to nutritional supplements. North Bergen, NJ, USA: Basic Health Publications, Inc.

Chapman R.F. \& Joern A., 1990. Biology of grasshoppers. New York,USA: John Wiley \& Sons.

Das M. \& Mandal S., 2013. Assessment of nutritional quality and anti-nutritient composition of two edible grasshoppers (Orthoptera: Acrididae) - a search for new food alternative. Int. J. Med. Pharm. Sci., 3(5), 31-48.

DeFoliart G.R., 1997. An overview of the role of edible insects in preserving biodiversity. Ecol. Food Nutr., 36(2-4), 109-132.

DeFoliart G.R., 1999. Insects as food. Annu. Rev. Entomol., 44, 21-50.

Ekpo K.E., 2011. Effect of processing on the protein quality of four popular insects consumed in Southern Nigeria. Arch.Appl.Sci.Res., 3(6), 307-326.

El-Mallakh O.S. \& El-Mallakh R.S., 1994. Insects of the Qur'an. Am. Entomol., 40(2), 82-84.

Fiala N., 2008. Meeting the demand. Ecol. Econ., 67(3), 412-419.

Fink M. et al., 2004. An experimental infection model for Tetrameres americana (Cram 1927). Parasitol. Res., 95(3), 179-185.

Finke M.D. \& Oonincx D., 2014. Chapter 17. Insects as food for insectivores. In: Morales-Ramos J.A., Rojas M.G. \& Shapiro-Ilan D.I., eds. Mass production of beneficial organisms. Invertebrates and entomopathogens. San Diego, CA, USA: Academic Press, 583-616.

Food and Agriculture Organization, 2001. Desert locust guidelines: biology and behavior. $2^{\text {nd }}$ ed. Roma: FAO.

Haldar P., Das A. \& Gupta R.K., 1999. A laboratory based study on farming of an Indian grasshopper Oxya fuscovittata (Marschall) (Orthoptera: Acrididae). J. Orthoptera Res., 8, 93-97.

Hanafi Y.S., 2012. Trend of agricultural development. In: Ecology and agriculture in the Himalayan region: 
problems and prospects of agricultural development in North Western Himalayas. New Delhi: Concept Publishing Company Private Limited, 444.

Hanboonsong Y., Jamjanya T. \& Durst P., 2013. Sixlegged livestock: edible insect farming, collecting and marketing in Thailand. Bangkok: Food and Agriculture Organization.

Hartin J., Geisel P.M. \& Unruh C.L., 2001. Lawn watering guide for California. Oakland, CA, USA: University of California ANR Publications.

Hill J.G. \& Goddard J., 2012. Medical and veterinary importance of grasshoppers, katydids, and crickets (Hexapoda: Orthoptera). J. Mississipi Acad. Sci., 57(23), 172-177.

Jongema E., 2015. World list of edible insects. Wageningen, The Netherlands: Wageningen University.

Kelemu S. et al., 2015. African edible insects for food and feed: inventory, diversity, commonalities and contribution to food security. J. Insects Food Feed, 1(2), 103-119.

King D.A. et al., 2006. Infectious diseases: preparing for the future. Science, 313(5792), 1392-1393.

Kinyuru J., Kenji G.M., Muhoho S.N. \& Ayleko M., 2011. Nutritional potential of Lognhorn grasshopper (Ruspolia differens) consumed in Siaya district, Kenya. J. Agric. Sci. Technol., 12(1), 32-46.

Ladron de Guevara O. et al., 1995. Amino acid determination in some edible Mexican insects. Amino Acids, 9(2), 161173.

Linus Pauling Institute. Micronutrient Information Center. Corvallis, OR, USA: Linus Pauling Institute.

Lundy M.E. \& Parrella M.P., 2015. Crickets are not a free lunch. PloS One, 10(4), e0118785.

Lye K., 1997. Temperate climates. Raintree Steck-Vaughn.

Melo V. et al., 2011. Quality proteins from edible indigenous insect food of Latin America and Asia. Emirates J. Food Agric., 23(3), 283-289.

Meyer-Rochow V.B., 2009. Food taboos. J. Ethnobiol. Ethnomed., 5, 18.

Mlcek J., Rop O., Borkovcova M. \& Bednarova M., 2014. A comprehensive look at the possibilities of edible insects as food in Europe - a review. Pol. J. Food Nutr. Sci., 64(3), 147-157.

Msangi S. \& Rosegrant M.W., 2011. Feeding the future's changing diets: implications for agriculture markets, nutrition, and policy. In: Proceedings of the 2020 conference, Leveraging agriculture for improving nutrition and health, February 10-12, 2011, New Delhi, India. Washington: IFPRI.

Oonincx D.G.A.B.et al.,2010.An exploration on greenhouse gas and ammonia production by insect species suitable for animal or human consumption. PLOS ONE, 5(12), e14445.

Oonincx D.G.A.B. \& van der Poel A.F.B., 2011. Effects of diet on the chemical composition of migratory locusts (Locusta migratoria). Zoo Biol., 30(1), 9-16.
Oonincx D.G.A.B. \& de Boer I.J.M., 2012. Environmental impact of the production of mealworms as a protein source for humans - a life cycle assessment. PloS One, 7(12), e51145.

Pener M.P., 2014. Allergy to locusts and acridid grasshoppers. J. Orthoptera Res., 23(1), 59-67.

Ramos-Elorduy de Conconi J. \& Pino Moreno J.M., 1988. The utilization of insects in the empirical medicine of ancient Mexicans. J. Ethnobiol., 8(2), 195-202.

Ramos-Elorduy J. et al., 1997. Nutritional value of edible insects from the state of Oaxaca, Mexico. J. Food Compos. Anal., 10(2), 142-157.

Ramos-Elorduy J. \& Pino Moreno J.M., 2001a. El consumo de insectos entre los lacandones de la comunidad Bethel y su valor nutritivo. Etnobiología, 1, 24-43.

Ramos-Elorduy J. \& Pino J.M., 2001b. Contenido de vitaminas de algunos insectos comestibles de México. J. Mex. Chem. Soc., 45(2), 66-76.

Ramos-Elorduy J., Medeiros Costa Neto E., Pino J.M. \& Zetina D.H., 2007. Knowledge about useful entomofauna in the county of La Purisima Palmar de Bravo, Puebla State, Mexico. Biotemas, 20(2), 121-134.

Ramos-Elorduy Blasquez J.., Pino Moreno J.M. \& Martinez Camacho V.H., 2012. Could grasshoppers be a nutritive meal? Food Nutr. Sci., 3(2), 164-175.

Roffey J., 1979. Locusts and grasshoppers of economic importance in Thailand. London: Centre for Overseas Pest Research.

Rumpold B.A. \& Schlüter O.K., 2013. Nutritional composition and safety aspects of edible insects. Mol. Nutr. Food Res., 57(5), 802-823.

Seino R.A. et al., 2013. An inventory of short horn grasshoppers in the Menoua division, West region of Cameroon. Agric. Biol. J. North Am., 4(3), 291299.

Shockley M. \& Dossey A.T., 2014. Chapter 18 - Insects for human consumption. In: Morales-Ramos J.A., Rojas M.G. \& Shapiro-Ilan D.I., eds. Mass production of beneficial organisms. Invertebrates and entomopathogens. San Diego, CA, USA: Academic Press, 617-652.

Siriamornpun S. \& Thammapat P., 2008. Insects as a delicacy and a nutritious food in Thailand. Chapter 16. In: Robertson G.L. \& Lupien J.R., eds. Using food science and technology to improve nutrition and promote national development. Oakville, ON, Canada: International Union of Food Science \& Technology.

Solomon M., Ladeji O. \& Umoru H., 2008. Nutritional evaluation of the giant grasshopper (Zonocerus variegatus) protein and the possible effects of its high dietary fibre on amino acids and mineral bioavailability. Afr. J. Food Agric. Nutr. Dev., 8(2), 238-248.

Stargrove M.B., Treasure J. \& McKee D.L., 2008. Herb, nutrient, and drug interactions. Elsevier Health Sciences.

Steinfeld H. et al., 2006. Livestock's long shadow. Environmental issues and options. Roma: FAO. 
Tan H.S.G. et al., 2015. Insects as food: exploring cultural exposure and individual experience as determinants of acceptance. Food Qual. Preference, 42, 78-89.

Torres P. et al., 2011. Estudio entomofaunístico del cultivo de amaranto (Amaranthus hypochondriacus L.) en Puebla México. Rev. Mex. Cienc. Agríc., 2(3), 359-371.

U.S. Environmental Protection Agency, 2015. Inventory of U.S. greenhouse gas emissions and sinks: 1990-2013. Washington: U.S. Environmental Protection Agency.

van Huis A., 2013. Potential of insects as food and feed in assuring food security. Annu. Rev. Entomol., 58, 563583.

van Huis A. et al., 2013. Edible insects: future prospects for food and feed security. Roma: FAO, 1-201.

Verbeke W., 2015. Profiling consumers who are ready to adopt insects as a meat substitute in a Western society. Food Qual. Preference, 39, 147-155.

WHO, 2004. Vitamin and mineral requirements in human nutrition. Report of a joint FAO/WHO expert consultation, Bangkok, Thailand, 21-30 September 1998. $2^{\text {nd }}$ ed. Geneva, Switzerland: WHO.

WHO, 2007. Protein and amino acid requirements in human nutrition. WHO technical report series 935. Geneva, Switzerland: WHO.

Womeni H.M. et al., 2009. Oils of Oryctes owariensis and Homorocoryphus nitidulus consumed in Cameroon: sources of linoleic acid. J. Food Technol., 7(2), 54-58.
Womeni H.M. et al., 2012. Nutritional value and effect of cooking, drying and storage process on some functional properties of Rhynchophorus phoenicis. Int. J. Life Sci. Pharma Res., 2(3), 203-219.

Woodham A.A., 2012. The domestic non-ruminant animal as consumer and provider of protein. In: Pirie N.W., ed. Food protein sources. Cambridge,UK: Cambridge University Press.

Yang L.-F., Siriamornpun S. \& Li D., 2006. Polyunsaturated fatty acid content of edible insects in Thailand. J. Food Lipids, 13(3), 277-285.

Yen A.L., 2009. Edible insects. Entomol. Res., 39(5), 289298.

Yhoung-aree J., 2008. Edible insects in Thailand: nutritional values and health concerns. In: Durst P.B., Johnson D.V., Leslie R.N. \& Shono K., eds. Forest insects as food: humans bite back, Proceedings of a workshop on AsiaPacific resources and their potential for development, February 19-21, 2008, Chiang Mai, Thailand. Bangkok: FAO.

(70 ref.) 